\title{
PENGARUH PENGGUNAAN MODEL PEMBELAJARAN PROBLEM SOLVING TERHADAP PENINGKATAN HASIL BELAJAR MATEMATIKA SISWA SMP DI DAERAH TERTINGGAL
}

\author{
Anuwar Kadir Abdul Gafur ${ }^{1 *}$, Ardin Umar ${ }^{2}$ \\ ${ }^{1}$ Prodi Matematika, Fakultas Matematika dan Ilmu Pengetahuan Alam, Universitas Pasifik Morotai \\ ${ }^{2}$ Prodi Akuntasi, Fakultas Ekonomi, Universitas Pasifik Morotai \\ Jalan Siswa, Kampus UNIPAS, Darame, Morotai, Indonesia \\ e-mail: 1anuwarkadir657@gmail.com; \\ Submitted: September 29, 2020 \\ Revised: October 1, 2020 \\ Accepted: October 7, 2020 \\ corresponding author*
}

\begin{abstract}
Abstrak
Tujuan penelitian untuk mengetahui bagaimana hasil belajar siswa pada materi pola bilangan melalui model pembelajaran Problem Solving, serta mengetahui apakah terdapat perbedaan hasil belajar siswa pada materi pola bilangan antara model pembelajaran Problem Solving dengan konvensional. Penelitian ini merupakan penelitian eksperimen yang menggunakan dua kelas yaitu kelas VIIIA dengan menerapkan model pembelajaran konvensional dan kelas VIIIB menggunakan model pembelajaran problem solving, Populasi pada penelitian ini adalah seluruh siswa kelas VIII SMP Negeri 5 Satap Maba yang merupakan salah satu sekolah yang berada pada daerah tertinggal. Sampel yang diambil adalah siswa kelas VIIIA berjumlah 24 siswa dan VIIIB berjumlah 25 siswa analisis data menggunakan chi-kuadrat untuk normalitas data statistik uji parametrik yaitu uji t dengan berbantuan SPSS 25. Berdasarkan hasil penelitian dapat disimpulkan bahwa: (i) Hasil belajar siswa kelas VIIB SMP Negeri 5 Satap Maba pada materi pola bilangan setelah diberikan perlakuan dengan menerapkan model pembelajaran Problem Solving, dapat dilihat bahwa terdapat 1 siswa (4\%) berkualifikasi baik sekali atau memuaskan, terdapat 5 siswa (20\%) berkualifikasi baik, terdapat 11 siswa (44\%) berkualifikasi cukup, terdapat 7 siswa (28\%) berkualifiksi kurang, terdapat 1 siswa (4\%) berkualifikasi sangat kurang. (ii) Berdasarkan uji-t, pada taraf nyata $\alpha=0.05$ dan nilai Sig. adalah 0,022 maka $\mathrm{H}_{1}$ diterima. Hal ini menunjukkan bahwa terdapat perbedaan hasil belajar antara model pembelajaran Problem Solving dan pembelajaran konvensional yang diterapkan terhadap peningkatan hasil belajar siswa pada pola bilangan
\end{abstract}

Kata Kunci: pembelajaran problem solving, pembelajaran konvensional, kesulitan belajar

\section{Pendahuluan}

Matematika merupakan mata pelajaran yang memiliki peranan penting dalam ilmu pengetahuan. Hal tersebut dapat dicermati pada tingkatan sekolah, mulai dari Sekolah Dasar (SD), Sekolah Menegah Pertama (SMP), Sekolah Menegah Atas (SMA), dan Perguruan Tinggi sehingga keberadaan matematika disetiap tingkatan sekolah harus mempelajari matematika. Menurut R. Soedjadi (2000:13), Mempelajari matematika, siswa diharapkan adanya perubahan pola pikir setelah mempelajari matematika. Terkait dengan itu, dalam belajar matematika terdapat karakteristik matematika yang salah satunya adalah objek matematika. Dalam matematika objek dasar yang dipelajari adalah abstrak, sering juga disebut objek mental. Objek-objek itu merupakan objek pikiran. Objek dasar itu meliputi fakta, konsep, operasi ataupun relasi, dan prinsip. Dari objek dasar itulah disusun suatu pola dan struktur matematika. Lebih lanjut diterangkan pula, menurut Soemoenar, dkk, (2007:1.11) bahwa ada dua objek matematika yang dipelajari di sekolah yaitu objek langsung pembelajaran matematika dan objek tak langsung pembelajaran matematika. Objek langsung yaitu pembelajaran matematika meliputi fakta, konsep, prinsip, dan keterampilan/ operasi/ skill. Objek tak langsung yaitu pembelajaran matematika diantaranya adalah disiplin diri, kemahiran matematika, apresiasi terhadap matematika, dan berpikir secara matematis yaitu logis, rasional dan eksak. Pada hakekatnya belajar matematika sangat terkait dengan berfikir matematis. Menurut Herman Hudoyo, berfikir matematis adalah merumuskan suatu himpunan yang telah diketahui atau berhubungan dengan struktur-struktur yang secara mantap telah terbentuk dari hal-hal yang ada sebelumnya.

Copyright (C) Authors. This is an open access article distributed under the Attribution-NonCommercialShareAlike 4.0 International (CC BY-NC-SA 4.0), which permits unrestricted use, distribution, and reproduction in any medium, provided the original work is properly cited. 
Belajar merupakan salah satu hal pokok dalam pendidikan. Secara psikologi, belajar merupakan suatu proses perubahan tingkah laku sebagai hasil dari interaksi dengan lingkungannya. Menurut Slameto (2003:2), belajar ialah suatu proses usaha yang dilakukan seseorang untuk memperoleh suatu perubahan tingkah laku yang baru secara keseluruhan, sebgai hasil pengalamannya sendiri dalam interaksi dengan lingkungannya. Menurut Trianto (2011:16), proses belajar terjadi melalui banyak cara salah satunya melalui latihan atau pengalaman, baik disengaja maupun tidak disengaja dan berlangsung sepanjang waktu dan menuju pada suatu perubahan pada diri pembelajar. Perubahan yang dimaksud adalah perubahan prilaku tetap berupa pengetahuan, pemahaman, ketrampilan, dan kebiasaan yang baru diperoleh individu. Sedangkan pengalaman merupakan interaksi antara individu dengan lingkungan sebagai sumber belajarnya. Jadi, belajar dapat diartikan sebagai proses perubahan prilaku dari sesuatu yang belum diketahui menjadi hal yang diketahui, daritidak paham menjadi paham, dari kurang trampl menjadi lebih terampil, dan dari kebiasaan lama menjadi kebiasaan baru, serta bermanfaat bagi lingkungan dan individu itu sendiri.

Berdasarkan pengertian belajar yang telah dipaparkan, bahwa indikator keberhasilan suatu proses belajar adalah adanya perubahan tingkah laku. Yang mana tingkah laku manusia terdiri dari sejumlah aspek. Sehingga, bila salah satu aspek saja sudah berubah dalam artian positif, maka bisa disimpulkan proses belajarnya telah berhasil. Adapun aspek-aspek itu menurut pembagian Hamalik (2005:30) adalah: (1). Pengetahuan, (2). Pengertian, (3). Kebiasaan, (4). Keterampilan, (5). Apresiasi, (6). Emosional, (7). Hubungan sosial, (8). Jasmani, (9). Etis atau budi pekerti, dan (10). Sikap. Hasil belajar matematika adalah hasil perubahan yang dialami oleh pembelajar dalam menyelesaikan permasalahan dengan menggunakan prinsip-prinsipnya. Hal ini tidak hanya terbatas dalam menyelesaikan soal tugas atau ulangan matematika, tetapi lebih mengarah kepada pemikiran yang logis, sistematis dan selalu peka terhadap masalah-masalah yang timbul di lingkungan sekitar untuk dipecahkan.

Berdasarkan Peraturan Presiden (perpres) Nomor 131 Tahun 2015 tentang penetapan Daerah Tertinggal Tahun 2015-2019. Dalam perpes disebutkan, daerah tertinggal yaitu daerah kabupaten yang wilayah serta masyarakat kurang berkembang dibandingkan dengan daerah lain dalam skala nasional. Dalam penetapan perpres tentang daerah tertinggal, berdasarkan kriteria yaitu : (a) Perekonomian masyarakat; (b) Sumber daya manusia; (c) Sarana dan prasarana; (d) Kemampuan keuangan; (e) Aksesibilitas; dan (f) Karakteristik daerah. Dalam peraturan tersebut, salah satu daerah yang memiliki kriteria tersebut sehingga dikatagorikan sebagai daerah tertinggal adalah Kabupaten Halmahera Timur Provinsi Maluku Utara yang berada didaerah pesisir Kecamatan Maba Utara pada Desa Jara-jara.

Pendidikan matematika di SMP pada daerah tertinggal sebagai wahana pendidikan untuk meningkatkan potensi yang dimiliki siswa. Potensi tesebut meliputi kemampuan bernalar, kemampuan memecahkan masalah, kreativitas, kebiasaan berkerja keras dan madiri, jujur, berdisiplin, memiliki sikap sosial yang baik, serta berbagai ketrampilan yang diperlukan dalam hidup bermasyarakat. Selain kemampuan dan sikap di atas, pendidikan matematika di sekolah juga harus dapat membekali siswa dengan pengetahuan, kemampuan dan ketrampilan dasar matematika agar lulusannya melek matematika. Dalam upaya memenuhi harapan di atas dan mengantisipasi berbagai perubahan di masa datang, perlu kiranya para guru, pendidik, dan pejabat yang terkait memahami aspek pembelajaran matematik. Oleh karena itu, diperlukan suatu desain pembelajaran yang menyenangkan sehingga terjadinya perubahan peningkatan hasil belajar. Maka desain pembelajaran matematika adalah Model pembelajaran problem solving atau pemecahan masalah. Menurut Ibrahim (Trianto, 2007:70) model pembelajaran problem solving berusaha membantu siswa menjadi pelajar yang mampu mengembangkan kemampuan berpikir, memecahkan masalah, dan keterampilan intelektual; belajar berbagai peran orang dewasa melalui keterlibatan mereka dalam pengalaman nyata atau simulasi; dan menjadi pelajar yang otonom dan mandiri. Dengan demikian, Pembelajaran problem solving (pemecahan masalah) adalah pembelajaran yang didasarkan pada banyaknya permasalahan yang membutuhkan penyelidikan autentik yakni penyelidikan yang membutuhkan penyelesaian nyata dari permasalahan yang nyata (Trianto, 2007:67).

Pengunaan model pembelajaran dalam pelaksanaan pembelajaran merupakan salah satu peran yang sangat penting, karena tanpa menggunakan model pembelajaran yang tepat akan mempengaruhi hasil belajar siswa dalam berproses pembelajaran tersebut. Berdasarkan hasil wawancara dengan guru matematika yang mengajar kelas VIII SMP Negeri 5 Satap Maba masih tergolong rendah, yang disebabkan minimnya minat belajar siswa, sehingga sebagian 
besar tidak memenuhi kriteria ketuntasan minimum yang disingkat KKM kurikulum 2013 yang telah ditetapkan disekolah, yaitu 70. Hal tersebut berindikasi bahwa siswa mempunyai masalah dalam proses pembelajaran matematika.

\section{Metode Penelitian}

Metode penelitian ini adalah penelitian eksperimen dengan rancangan adalah two groups pretest-posttest design. Eksperimen selalu dilakukan dengan maksud untuk melihat dampak yang ditimbulkan oleh model pembelajaran pemecahan masalah (Problem Solving) dalam upaya mengatasi kesulitan belajar, dilihat peningkatan hasil belajar siswa kelas VIII SMP Negeri 5 Satap Maba pada pembelajaran matematika, khususnya pada materi Pola Bilangan. Rancangan penelitiannya dapat digambarkan sebagai berikut:

Tabel 1. Tabel rancangan penelitian

\begin{tabular}{cccc}
\hline Kelompok & Pre-test & Perlakuan & Post-test \\
\hline $\mathrm{K}_{P . S}$ & $\mathrm{Q}_{1}$ & $x_{1}$ & $\mathrm{Q}_{2}$ \\
$\mathrm{~K}_{\mathrm{K}}$ & $\mathrm{Q}_{1}$ & $x_{2}$ & $\mathrm{Q}_{2}$ \\
\hline
\end{tabular}

Keterangan:

$\mathrm{K}_{\mathrm{K}}$ : Kelompok pembelajaran konvensional

$\mathrm{K}_{P . S}$ : Kelompok eksperimen dengan menggunakan model pembelajaran pemecahan masalah (Problem Solving).

$x_{1} \quad$ : Perlakuan dengan konvensional

$x_{2}$ : Perlakuan dengan pembelajaran pemecahan masalah (Problem Solving)

$\mathrm{Q}_{1} \quad$ : Pemberian Pre-test

$\mathrm{Q}_{2} \quad$ : Pemberian Post-test

Dalam desain penelitian ini obsevasi dilakukan sebanyak dua kali yaitu sebelum dan setelah eksperimen. Observasi dilakukan sebelum eksperimen $\left(\mathrm{Q}_{1}\right)$ disebut test awal atau pre-test yang bertujuan untuk menganalisis kemampuan awal siswa sebelum diadakan perlakuan. Observasi setelah eksperimen $\left(\mathrm{Q}_{2}\right)$ disebut test akhir atau post-test yang bertujuan menganalisis kemampuan siswa setelah diadakan perlakuan. Perbedaan antara $\mathrm{Q}_{1}$ dan $\mathrm{Q}_{2}$ yakni $\mathrm{Q}_{2}-\mathrm{Q}_{1}$ diasumsikan merupakan efek dari perlakuan atau eksperimen. Populasi dalam penelitian ini adalah seluruh siswa SMP Negeri 5 Satap Maba. Sampel adalah bagian dari jumlah karakteristik yang dimiliki oleh populasi (Sugiyono, 2007:62). Dengan kata lain, sampel adalah bagian dari populasi. Sampel dalam penelitian ini adalah siswa kelas VIIIA dan VIIIB SMP Negeri 5 Satap Maba dengan jumlah siswa 49 siswa.

Variabel dalam penelitian ini adalah hasil belajar siswa yang diajarkan menggunakan model pembelajaran konvensional $\left(x_{1}\right)$ dan model pembelajaran pemecahan masalah (Problem Solving) $\left(x_{2}\right)$. Kedua variabel tersebut digunakan untuk membandingkan antara dua kelompok atau lebih dari suatu variabel tertentu. Perangkat pembelajaran yang disusun dalam penelitian ini terdiri dari Rencana Pelaksanaan Pembelajaran (RPP) untuk kelas kontrol dan eksperimen dengan masing-masing RPP 4 kali pertemuan serta pertemuan ke-5 kalinya pada masing-masing kelas diberikan test akhir. Lembar Kerja Siswa (LKS) dan bahan ajar digunakan dalam proses belajar mengajar di kelas eksperimen, karena LKS dan bahan ajar berada pada satu paket. Sedangkan pada proses pengajaran di kelas kontrol tidak mengunakan LKS dan bahan ajar, guru mengajar menggunakan model pembelajaran konvensional seperti biasanya, guru juga memberikan penguatan-penguatan dan memberikan pertanyaan kepada siswa selama pembelajaran berlangsung.

Instrumen yang akan digunakan dalam penelitian ini adalah berupa tes soal awal berbentuk essay berjumlah 5 butir soal, isian singkat 5 isian singkat, dan pilhan ganda 10 . Tes ini bertujuan untuk mengetahui kemampuan kognitif siswa sebelum perlakuan dan sesudah perlakuan dan soal disusun dengan memperhatikan kompetensi dasar. Setelah data hasil pre-test dan post test diperoleh maka dilakukan uji prasyarat analisis yaitu (1) Uji homogenitas untuk memperoleh asumsi bahwa sampel penelitian berawal dari kondisi yang sama atau homogen. Uji homogenitas dilakukan dengan menyelidiki apakah kedua sampel mempunyai varians yang sama atau tidak. Hipotesis yang digunakan dalam uji homogenitas adalah (a) $\mathrm{H}_{\mathrm{o}}$ merupakan sampel homogen, (b) $\mathrm{H}_{1}$ merupakan sampel tidak homogen. Untuk menguji kesamaan dua varians hasil belajar pre-test dengan menggunakan rumus sebagi berikut:

$$
\mathrm{F}_{\text {hitung }}=\frac{\text { Varians terbesar }}{\text { Varians terkecil }} \quad \text { Sudjana, 2002:250) }
$$

Untuk menguji apakah kedua varians hasil pre-test sama atau tidak maka $\mathrm{F}_{\text {hitung }}$ dikonsultasikan dengan $\mathrm{F}_{\text {tabel }}$ dengan taraf signifakan $\alpha=5 \%$ dengan $\mathrm{dk}$ pembilang = banyaknya data terbesar dikurangi satu dan dk penyebut = banyaknya data yang terkecil dikurangi satu. Jika $\mathrm{F}_{\text {hitung }}<\mathrm{F}_{\text {tabel }}$ maka $\mathrm{H}_{0}$ diterima. Yang berarti kedua kelompok tersebut mempunyai varians yang sama atau dikatakan homogen. (2) Uji normalitas dengan menggunakan rumus chi-kuadrat. Sedangkan untuk menganalisis data yang sesuai dengan rumusan masalah didepan dapat digunakan langkah-langkah yaitu (i) analisis hasil belajar siswa antara model pembelajaran pemecahan masalah dan pembelajaran konvensional 
menggunakan Penilaian Acuan Patokan (PAP) dengan konversi skala 5 sebagai berikut:

Tabel 2. Tabel Penilaian Acuan Patokan (PAP) (Thoha, 2003:89)

\begin{tabular}{cc}
\hline Taraf penguasaan & Kualifikasi \\
\hline $91 \%-100 \%$ & Memuaskan \\
$81 \%-90 \%$ & Baik \\
$71 \%-80 \%$ & Cukup \\
$61 \%-70 \%$ & Kurang \\
$<60 \%$ & Gagal \\
\hline
\end{tabular}

(ii) Perbedaan rata-rata hasil belajar siswa dari model yang diterapkan menggunakan uji kesamaan rata-rata (Sugiono, 2007:273). Data dioleh dengan menggunakan softwere SPSS 25. Berdasarkan hal ini, uji analisis data yang digunakan adalah uji $\mathrm{T}$ dengan hipotesis sebagai berikut.

$H_{0}: \mu_{1}=\mu_{2}$, tidak ada perbedaan hasil belajar siswa kelas VIII SMP Negeri 5 Satap Maba yang diterapkan dengan menggunakan model pembelajaran problem solving dan konvensional pada materi pola bilangan

$H_{1}: \mu_{1} \neq \mu_{2}$, ada perbedaan hasil belajar siswa kelas VIII SMP Negeri 5 Satap Maba yang diterapkan dengan menggunakan model pembelajaran problem solving dan konvensional pada materi pola bilangan.

Jika tidak terjadi peningkatan dengan melihat perbedaan rata-rata pada hasil belajar siswa dari penerapan model pembelajaran dan $\mathrm{H}_{0}$ diterima maka tidak terdapat pengaruh dalam penggunaan model pembelajaran terhadap peningkatan hasil belajar matematika. Sedangan jika terjadi peningkatan hasil belajar siswa berdasarkan perbedaan rata-rata pada hasil belajar siswa dari penerapan model pembelajaran dan terima $\mathrm{H}_{1}$ maka terdapat pengaruh dalam penggunaan model pembelajaran terhadap peningkatan hasil belajar matematika.

\section{Hasil dan Pembahasan}

\subsection{Hasil}

Sebelum peneliti memberikan pembelajaran kepada dua kelas yang peneliti jadikan sampel, peneliti melakukan observasi dengan cara bertanya kepada guru mata pelajaran kelas VIII SMP Negeri 5 Satap Maba dengan tujuan memperoleh informasi bahwa kedua kelas yang peneliti jadikan sampel adalah kelas yang mempunyai hasil belajar Matematika yang sama, selain itu juga peneliti memberikan tes awal untuk menguji homogenitas antara kedua kelas tersebut. Setelah peneliti memberikan tes awal, peneliti memeriksa dan menghitung hasil tes awal kedua kelas tersebut.
Setelah peneliti memberikan tes awal, peneliti memeriksa dan menghitung hasil tes awal kedua kelas tersebut. Uji homogenitas yang peneliti gunakan adalah uji $\mathrm{F}$. Varians $\mathrm{X}_{1}=58,13$ dan varians $\mathrm{X}_{2}=68,11$ sehingga diperoleh $\mathrm{F}_{\text {hitung }}=$ 1,171. Pada taraf nyata atau $\alpha=5 \%$ dan dk pembilang 24 serta $\mathrm{dk}$ penyebut $=23$, diperoleh $\mathrm{F}_{\text {tabel }}=2,01$. Hal ini menunjukkan $\mathrm{F}_{\text {hitung }}=1,18<$ $\mathrm{F}_{\text {tabel }}=2,01$ maka $\mathrm{H}_{0}$ diterima. Hal tersebut serupa pada nilai signifikansi (Sig.) based on mean yakni 0,544 lebih besar dari signifikan pengujian yakni $\alpha=0,05$, hal ini mengartikan bahwa $\mathrm{H}_{0}$ diterima. Dengan demikian, dapat dikatakan bahwa data yang diambil berasal dari sampel homogen.+

Tabel 3. Uji homogenitas

\begin{tabular}{ccccccc}
\hline Kelas & Sig. & $\alpha$ & Varian & $\mathrm{F}_{\text {hitung }}$ & $\mathrm{F}_{\text {tabel }}$ & Kesimpulan \\
\hline VIIIA & \multirow{2}{*}{0,544} & \multirow{2}{*}{0,05} & $\begin{array}{l}58,13 \\
68,11\end{array}$ & \multirow{2}{*}{1,17} & 2,01 & \multirow{2}{*}{$\mathrm{H}_{0}$ diterima } \\
VIIIB & & & & & \\
\hline
\end{tabular}

(diambil dari output SPSS 25)

Setelah itu, diperiksa dan dihitung hasil tes awal pada kedua kelas, kemudian dianalisis dengan PAP skala 5 berdasarkan tabel 2 sehingga dapat diketahui secara keseluruhan hasil tes awal menunjukan bahwa seluruh siswa gagal. Selain itu, peneliti membandingan kemampuan rata-rata siswa dikedua kelas tersebut. Setelah dibandingkan ternyata nilai rata-rata hasil tes awal antara kedua kelas tersebut tidak terlalu berbeda seperti yang terlihat pada tabel 4.

Tabel 4. Rata-rata kemampuan matematika dasar pada hasil pre-test

\begin{tabular}{cc}
\hline Kelas & Nilai rata-rata hasil tes awal \\
\hline VIIIA & 42,43 \\
VIIIB & 39,02 \\
\hline
\end{tabular}

(diambil dari output SPSS 25)

Kelas VIIIB dipilih sebagai kelas eksperimen dengan menggunakan model pembelajaran problem solving dan VIIIA dipilih sebagai kelas kontrol dengan menggunakan model pembelajaran konvensional. Pada kelas eksperimen siswa dibantu menggunakan perangkat pembelajaran yaitu, LKS dan bahan ajar yang diberikan sesuai dengan indikator, selanjutnya siswa mengamati bahan ajar dan LKS yang diberikan. Sedangan pada kelas kontrol peneliti memberikan materi sesuai dengan tahapan-tahapan pembelajaran sesuai dengan model pembelajaran yang diterapkan.

Setelah memberikan tes awal, pada pertemuan berikut peneliti memberikan pembelajaran yaitu pada kelas eksperimen dengan model Pembelajaran Problem Solving dan pada kelas dengan model Pembelajaran konvensional. Selanjutnya peneliti memberikan tes akhir kepada kedua kelas. Tes akhir ini tujuannya untuk melihat 
peningkatan hasil belajar siswa dari masingmasing model pembelajaran yang telah diterapkan.
Hasil tes akhir kemudian dianalisis dengan PAP skala 5 .

Tabel 5. Hasil Post-test pada kemampuan matematika dasar

\begin{tabular}{|c|c|c|c|c|c|c|}
\hline \multirow[b]{2}{*}{ Interval } & \multirow[b]{2}{*}{$\begin{array}{l}\text { Nilai } \\
\text { Huruf }\end{array}$} & \multirow[b]{2}{*}{ Kualifikasi } & \multicolumn{4}{|c|}{ Jumlah siswa } \\
\hline & & & $\begin{array}{c}\text { Kelas } \\
\text { Eksperimen }\end{array}$ & $\begin{array}{c}\text { Presentase } \\
(\%)\end{array}$ & $\begin{array}{c}\text { Kelas } \\
\text { Kontrol }\end{array}$ & $\begin{array}{c}\text { Presentase } \\
(\%)\end{array}$ \\
\hline$x>90$ & $\mathrm{~A}$ & Baik Sekali & 1 & 4 & 0 & 0 \\
\hline $75<x \leq 90$ & B & Baik & 5 & 20 & 3 & 12,5 \\
\hline $60<x \leq 75$ & $\mathrm{C}$ & Cukup & 11 & 44 & 7 & 29,2 \\
\hline $40<x \leq 60$ & $\mathrm{D}$ & Kurang & 7 & 28 & 10 & 41,7 \\
\hline$x<40$ & $\mathrm{E}$ & $\begin{array}{l}\text { Sangat } \\
\text { kurang }\end{array}$ & 1 & 4 & 4 & 16,6 \\
\hline & Jumlah & & 25 & 100 & 24 & 100 \\
\hline
\end{tabular}

Berdasarkan hasil post-test pada kemampuan matematika dasar pada tabel 5, menunjukkan bahwa terdapat 1 kualifikasi baik dengan presentase $4 \%$ pada kelas eksperimen dan untuk kelas kontor tidak terdapat kualifikasi baik pada siswa. Pada kualifikasi baik untuk kelas eksperimen terdapat 5 siswa dengan presentasi $20 \%$ sedangan kelas kontrol terdapat 3 responden dengan presentasi $12,5 \%$. Untuk kualifikasi cukup pada kelas eksperimen terdapat 11 responden dengan presentase $44 \%$ sedangkan pada kelas kontrol memiliki 7 responden dengan presentase $29,2 \%$. Pada kualifikasi kurang pada kelas eksperimen terdapat 7 responden dengan presentase $28 \%$ dan untuk kelas kontrol terdapat responden sebanyak 10 dengan responden $41,7 \%$. Pada kualifikasi sangat kurang, untuk kelas eksperimen terdapat 1 reponden dengan presentasi $4 \%$ dan kelas kontrol terdapat 4 responden dengan presentase $16,6 \%$. Selanjutnya untuk rata-rata hasil belajar siswa setelah melakukan perlakuan pada kedua kelas, dapat dilihat pada tabel 6 sebagi berikut.

Tabel 6. Rata-Rata Hasil Belajar Siswa

\begin{tabular}{lc}
\hline \multicolumn{1}{c}{ Kelas } & Rata-rata \\
\hline Kontrol & 59,30 \\
Eksperimen & 67,30 \\
\hline
\end{tabular}

Dari tabel 3, terlihat bahwa rata-rata hasil belajar siswa pada kelas kontrol lebih kecil dari pada kelas eksperimen. Oleh karena itu, peneliti ingin mengetahui sampel yang digunakan normal atau tidak, maka diperlukan perhitungan Chisquare pada kedua kelompok yaitu kelas kontrol dan kelas eksperimen sehingga diperoleh hasil pada tabel berikut ini.

Tabel 7. Hasil Uji Normalitas $(\alpha=0,05)$

\begin{tabular}{cccc}
\hline Kelas & Sig. & $\alpha$ & Kesimpulan \\
\hline Kontrol & 0,182 & \multirow{2}{*}{0,05} & \multirow{2}{*}{ Terima $\mathrm{H}_{0}$} \\
Eksperimen & 0,251 & & \\
\hline (diambil dari output & SPSS 25) & &
\end{tabular}

Pada tabel 7, nilai Signifikansi untuk kelas kontrol dan eksperimen adalah 0,182 dan 0,251, masing-masing. Terlihat bahwa pada kelas eksperimen lebih besar dari $\alpha=0,05$ sedangan hal tersebut juga terjadi pada kelas kontrol, dimana dilai Sig. lebih besar dari $\alpha=0,05$. Hal ini menunjukkan bahwa $\mathrm{H}_{1}$ ditolak dan terima $\mathrm{H}_{0}$. Dengan demikan dapat disimpulkan data yang diambil adalah sampel yang berdistribusi normal.

Selanjutnya untuk menguji hipotesis yakni terpadat perbedaan hasil belajar siswa antara kelas yang diajarkan dengan model pembelajaran problem solving dan model pembelajaran konvensional maka dilakukan dilakuakn uji hipotesis dengan menggunakan uji beda rata-rata atau uji-t. Adapun hasil yang diperoleh dari kedua perlakuan tersebut dapat dilihat pada tabel 8 .

Tabel 8. Hasil Pengujian Hipotesis dengan

\begin{tabular}{lccc}
\multicolumn{4}{c}{ Menggunakan Uji-t $(\alpha=0,05)$} \\
\hline \multicolumn{1}{c}{ Kelas } & Sig. & $\alpha$ & Kesimpulan \\
\hline $\begin{array}{l}\text { Kontrol } \\
\text { Eksperimen }\end{array}$ & 0,022 & 0,05 & Terima $\mathrm{H}_{1}$ \\
\hline
\end{tabular}

(diambil dari output SPSS 25)

Pada tabel 8, menunjukkan nilai Sig. (2tailed) lebih kecil dari $\alpha$ yaitu 0,022 lebih kecil dari 0,05 . Akibatnya $H_{1}$ diterima dan menolak $H_{0}$. Dengan demikian ada perbedaan hasil belajar siswa kelas VIII SMP Negeri 5 Satap Maba yang diterapkan dengan menggunakan model pembelajaran problem solving dan konvensional pada materi pola bilangan. Dengan demikian, terdapat pengaruh dalam penggunaan model pembelajaran terhadap peningkatan hasil belajar siswa dalam menyelesaikan masalah pada pola bilangan.

\subsection{Pembahasan}

Sebelum melaksanakan kegiatan belajar mengajar dengan menerapkan model pembelajaran Problem Solving pada pola bilangan peneliti mengadakan tes awal guna mengukur kemampuan 
siswa pada kedua kelas kontrol dan eksperimen. Secara umum, dapat dikatakan bahwa kemampuan awal siswa dalam menyelesaikan soal matematika dasar masih tergolong rendah. Hal ini dilihat dari nilai rata-rata pada kedua kelas yaitu 42,43 untuk kelas VIIIA dan 39,02 untuk VIIIB.

Pertemuan selanjutnya, peneliti mengajarkan materi pola bilangan dengan model pembelajaran yang berbeda yaitu pada kelas VIIIA dengan model pembelajaran konvensional sebagai kelas kontrol dan pada kelas VIIIB dengan model pembelajaran problem solving sebagai kelas eksperimen. Hal tersebut nampak pada perbedaan rata-rata hasil belajar siswa untuk kelas yang diajarkan dengan model pembelajaran problem solving memperoleh nilai rata-rata 67,30 lebih tinggi dari kelas yang diajarkan dengan menggunakan model pembelajaran konvensional.

Setelah memperoleh rata-rata hasil belajar siswa pada tes akhir dari kedua kelas tersebut, maka dilakukan perhitungan statistik untuk menguji perbandingan hasil belajar siswa kelas VIIIA yang menggunakan metode pembelajaran konvensional dan kelas VIIIB menggunakan pembelajaran Problem Solving dengan menggunakan uji-t. Hasil dari uji-t menunjukkan bahwa nilai Sig. (2-tailed) lebih kecil dari $\alpha$ sehingga dapat disimpulkan bahwa ada perbedaan hasil belajar siswa kelas VIII SMP Negeri 5 Satap Maba yang diterapkan dengan menggunakan model pembelajaran problem solving dan konvensional pada materi pola bilangan.

Perbedaan hasil belajar siswa pada kedua kelas tersebut menunjukan bahwa model pembelajaran problem solving memberikan pengaruh terhadap proses pembelajaran dan memberikan hasil yang lebih baik daripada model pembelajaran konvensional.

Siswa yang diajarkan dengan menggunakan model pembelajaran problem solving lebih aktif dalam proses pembelajaran karena dengan membagi kelompok dalam beberapa bagian. Siswa akan lebih fokus dalam menyelesaikan yang diberikan oleh peneliti, selain itu, pembagian siswa membuat siswa lebih aktif dalam berbagi pengetahuan dengan teman kelompok, sehingga siswa akan lebih bersaing dalam menyelesaikan masalah serta mendapatkan hasil yang lebih baik.

\section{Kesimpulan}

Berdasarkan uji-t, akibatnya $\mathrm{H}_{1}$ diterima. Hal ini menunjukkan bahwa terdapat perbedaan hasil belajar antara model pembelajaran Problem Solving dan pembelajaran konvensional yang diterapkan terhadap peningkatan hasil belajar siswa pada pola bilangan. Rata-rata hasil belajar pada kelas eksperimen lebih besar dari pada kelas kontrol, maka terjadi peningkatan hasil belajar siswa dengan menerapkan model pembelajaran problem solving. Akibatnya terdapat pengaruh penggunaan model pembelajaran problem solving terhadap peningkatan hasil belajar siswa pada materi pola bilangan di SMP Negeri 5 Satap Maba yang merupakan salah satu sekolah yang berada di daerah tertinggal.

\section{Daftar Pustaka}

Ahmadi dan Supriyono, (2004). Psikologi Belajar. Jakarta: Rineka Cipta.

Arikunto, S. (2008). Prosedur Penelitian Suatu Pendekatan Praktek. Jakarta: Rineka Cipta.

Dimyati dan Mudjiono, (2006). Belajar dan Pembelajaran. Jakarta: Rineka Cipta.

Djamarah, dan Zain. (2002). Strategi Belajar Mengajar. Jakarta: Rineka Cipta.

Hamalik, Oemar, (2005). Proses Belajar Mengajar, Cet 4. Jakarta: Bumi Aksara,

Lie, A. (2007). Cooperative Learning. Mempraktikkan Cooperative Learning Di Ruang-ruangKelas. Jakarta: Grasindo

Syah, M. (2002). Psikologi Belajar. Jakarta: Raja Grafindo Persada.

Surya, Muhammad, (2004). Psikologi Pembelajaran dan Pengajaran, Bandung.

Sugiyono. (2007). Statistik UntukPenelitian. Alfabeta. Bandung.

Sugiono. (2009). Metode Penelitian Pendidikan (Pendekatan Kualitatif, Kuantitatif, dan R\&D ). CV. Alfabeta. Bandung

Sudjana. (2002). Metoda Statistika. Bandung: Tarsito

Soedjadi, R., (2000). Kiat Pendidikan Matematika di Indonesia, Direktorat Jenderal Pendidikan Tinggi Departemen Pendidikan Nasional, Jakarta.

Trianto, (2007). Model-Model Pembelajaran Inovatif Berorientasi Konstruktivistik. Jakarta: Prestasi Pustaka Publisher.

Thoha, M. (2003). Teknik Evaluasi Pendidikan. Jakarta: Raja Grafindo Pertsada

Wono S Budhi, (2007). Matematika untuk SMP. Jakarta: Erlangga 